\title{
Lateral
}

JOURNAL OFTHE CULTURALSTUDIESASSOCIATION

Kate Siegfried, "Review of 'Premonitions: Selected Essays on the Culture of Revolt' by AK Thompson (AK Press)," Lateral 8.2(2019).

https://doi.org/10.25158/L8.2.15

This content is licensed under a Creative Commons Attribution 4.0 International License. Copyright is retained by authors.

Book Reviews

Issue 8.2 (Fall 2019)

\section{Review of Premonitions: Selected Essays on the Culture of Revolt by AK Thompson (AK Press)}

\section{Kate Siegfried}

\begin{abstract}
In this series of essays written over the last decade, AK Thompson offers a critical assessment of the analytical foundation underwriting contemporary social movement politics. Methodologically and conceptually influenced by Walter Benjamin, Thompson looks to visual culture, everyday life, and collective street actions as crystallizations of the logics saturating our culture of revolt. Through generative critique, creative conceptual development, and a consistent orientation toward identifying politically possibility, Premonitions lays the groundwork for social movement scholars and activists alike to develop a conceptual toolkit for moving beyond the mere existence of struggle as an end in itself.
\end{abstract}

Premonitions: Selected Essays on the Culture of Revolt. By AK Thompson. Chico, CA:

AK Press, 2018, 254 pp. (paperback) ISBN 9781849353380. US List: \$20.00.

Within the first few pages of Premonitions: Selected Essays on the Culture of Revolt, AK

Thompson describes not wanting to feel "at peace with or reconciled to a reality that debased us all." (2) This is a feeling likely shared by those who seek to fundamentally transform our current social reality. Indeed, to feel "at peace" or settled within our current violent social formation would be to accept it as is. A premonition is a strong feeling that something bad is about to happen. Although never explicitly articulated, it seems that Thompson offers the premonition not only as a sensation that merely happens to someone, but rather, as a mode of engagement through which one can identify political possibility and shake off the feeling of being "at peace." Premonition as a mode of engagement forces an active reckoning with the violent and exploitative future that will come to pass if present conditions are left unchanged. Importantly, Thompson does not simply uncover this dismal future, the logical conclusion of our current social reality, as an intellectual end in itself. Rather, his political method throughout this series of essays is to identify and highlight possibilities for antagonism and opportunity across different terrains of social struggle, including cultural production, everyday life, and collective street action. While numerous threads weave their way through the entirety of the book, Premonitions is divided into three sections: "catastrophe," "the critical moment," and "progress." The three sections are thematically distinct, yet Thompson's consistent political investment holds the text together. While he moves across a diverse array of topics, he does so with a diligent attentiveness to identifying and developing political opportunity from different facets of social life.

Extracted from Walter Benjamin, Thompson's methodological approach is one which isolates single objects as encapsulations of the social totality from which they emerged. Or, put more simply, Thompson locates the whole within the fragment. For Thompson, this methodological approach enables a collective grasp of specific movement shortcomings, 
thus enabling a sober assessment of how to recognize and take hold of political possibility. Importantly, Benjamin's presence is woven throughout the book, beginning with the title. Premonitions can almost certainly be understood in relation to two of Benjamin's most important texts, titled Illuminations and Reflections. While the acts of illumination and reflection are methodologically present in Premonitions as Thompson turns a critical eye to past social movement activities, Thompson's approach is distinct from Benjamin in so far as he actively attunes the reader to future time through the predictive sensation of the premonition. This intentional orientation toward the future remained somewhat more implicit, although not absent, in Benjamin's writings, as he generally turned explicitly toward the past as a primary force for revolutionary transformation.

The first section of the book, "catastrophe," includes four essays that analyze and identify "missed opportunities." One key animating question in this section (which appears again at smaller moments in subsequent sections) is what role violence should play in social movements. While the debate over violence continues to return time and time again, especially in the context of "diversity of tactics" Thompson makes an important intervention. He states that

while activists on both sides of the violence/nonviolence divide seem committed to their respective certainties, few would suggest that either position has brought us any closer to a collective understanding of what we must do to win. (18)

Instead of settling on "diversity of tactics" as the inclusive answer to this debate, Thompson breaks the conversation open by returning to Benjamin's "Critique of Violence," highlighting the delineation between law-preserving violence and violence which establishes a new legal framework. This pivots away from arguments predicated on measuring violence through a logic of harm, and instead, the measure of violence becomes "the degree to which the status quo is maintained or transformed." (19) As Thompson points out, by maintaining arguments predicated on the logic of measuring harm, deliberation and assessment of movement tactics are highly constrained. Instead of orienting toward the question of what it takes to win, which would, in turn, break open logics of capture, activists often replay the same arguments over and over. Thompson states, "...I can't shake the feeling that we've reached a point of intractability that makes learning new things impossible. We've already chosen sides. And what we want most is the fight." (21)

The second section, "the critical moment," turns to visual culture as key objects through which to index political possibility. Thompson's key contribution in this section is his demonstration of the utility of Benjamin's theorization of "wish images" and "dialectical images" for assessing the role of visual culture in social movements. As Thompson details, "wish images," are images that ignite a longing for an unrealized promise by harkening back to traces of a (mythic) past. Indeed, Thompson's argument throughout this section, as demonstrated through an analysis of anti-globalization art, is that within movement contexts wish images "signal the possibility that the human energies captured by capitalism might finally spill over and bring with them a moment of transformative intoxication" without substantively gesturing toward how this transformation will take place as a productive process. (91) Importantly, Thompson's argument is not that movements are merely drawn to wish images, but that wish images function as a structuring logic for political engagement. Here, the image of resistance and the accompanying intoxication becomes the end in itself, rather than strategic engagement rooted in a real assessment of existing conditions and what it takes to win. Instead, Thompson suggests we turn to Benjamin's "dialectical image," or images that simultaneously make visible "the promise of finally fulfilling the desire for happiness and 
the means by which that fulfillment might be achieved," as a tool for prompting the viewer to reckon with the gap between an unrealized wish and conditions as they actually are.

(134) Offering Diego Rivera's Man at the Crossroads (1933) and Pablo Picasso's Guernica (1937) as concrete crystallizations of the dialectical image, Thompson argues for the dialectical image as a useful reference point for those seeking to illuminate and make vulnerable the violent structures embedded in our society.

In the final section, "progress," Thompson attends to the analytical foundation of different forms of collective action, including occupation and black bloc tactics. While this section is less conceptually cohesive than prior sections, key themes (such as the question of violence or the wish image) reemerge as full-fledged tools for social analysis, while also leaving room for Thompson to make a series of creative and generative claims. These claims include understanding violence as a productive force as well as understanding the struggle for the urban commons as a battle for necropolis, or, that the living must forge an alliance with the dead in order to win. This final section performs the creative and imaginative thinking necessary for collectively solving social problems.

Thompson identifies his audience clearly in the introduction as "comrades who inhabit the radical scene's structure of feeling without misgiving." (3) While Thompson, at times, offers harsh critiques of these radical political spaces, he does not leave his imagined readers hanging out to dry. Rather, through generative critique, creative conceptual development, and a consistent orientation toward identifying politically possibility, Thompson generates the sense of a shared and ongoing political project. Premonitions lays the groundwork for social movement scholars and activists alike to develop a conceptual toolkit for moving beyond the mere existence of struggle as an end in itself.

․ㅡㅁo

\section{Kate Siegfried}

Kate Siegfried is a PhD Candidate and Distinguished Graduate Fellow studying Rhetoric \& Public Affairs in the Department of Communication at Texas A\&M University. Her research examines the communicative logics of political repression, as well as what theories of materialist rhetoric can offer contemporary liberation movements. Siegfried's recent work is published in Women's Studies in Communication (2019) as well as the Oxford Research Encyclopedia of Communication (2018).

\footnotetext{
(c) (1)

This work is licensed under a Creative Commons Attribution 4.0 International (CC BY) License, unless otherwise noted. ISSN 2469-4053
} 